\title{
Endocrinology of the pregnant Djungarian hamster Phodopus campbelli
}

\author{
H. E. Edwards, K. L. Jenkins, L. C. Mucklow, G. E. Erb and \\ K. E. Wynne-Edwards* \\ Department of Biology, Queen's University, Kingston, Ontario, Canada K7L 3N6
}

\begin{abstract}
Factors regulating maternal serum progesterone concentrations during pregnancy in the Djungarian hamster Phodopus campbelli were investigated through changes in (1) concentrations of progesterone and oestradiol in the serum and extracted corpus luteum, non-luteal ovary, and placenta during late pregnancy, (2) prolactin concentrations in the serum, and (3) mass of the fetus, placenta, corpus luteum and non-luteal ovary. Early pregnancy (days 1-4) was characterized by surges of prolactin, corpus luteum growth and increased corpus luteum activity as indicated by increases in luteal mass, progesterone content and serum progesterone concentration. During mid-pregnancy (days 8-11) there was a loss of prolactin surges and a halt in the growth of the corpus luteum, as indicated by stable luteal mass, progesterone content and serum progesterone concentrations that were comparable with those of day 4 of pregnancy. At the same time, the non-luteal ovary began to secrete oestradiol and, on day 12, preovulatory follicles of unknown function were found. During late pregnancy (days 14-17), the prolactin surge pattern was re-established, the non-luteal ovary and corpus luteum contained oestradiol, luteal cell growth caused an increase in corpus luteum size and mass, and serum progesterone concentrations doubled. As late-term pregnancies failed to survive bilateral ovariectomy and the placenta contained little extractable progesterone, it appears that the progesterone of Djungarian hamster pregnancy is synthesized by the corpus luteum throughout gestation.
\end{abstract}

\section{Introduction}

Conventional laboratory models including the rat, mouse and Golden hamster are useful for reproductive studies owing to their relatively invariant $4-5$-day oestrous cycle and the ease with which they breed in captivity (e.g. Murphy, 1985). However, other species with similarly short oestrous cycles and gestation periods differ from these common models in the hormonal regulation of critical reproductive events (for examples, see Carter et al., 1986; Rissman, 1990); such differences may have adaptive value for each species (Bronson, 1989).

The Djungarian hamster Phodopus campbelli has an oestrous cycle lasting 4 days with a spontaneous ovulation, but a signal from a breeding male is necessary to initiate this cycle (Erb et al., 1993) and to prevent pregnancy block (Wynne-Edwards $e t$ al., 1987a). Behavioural receptivity requires only physiological concentrations of oestradiol, and the pro-oestrous progesterone surge that is usually associated with ovulation and the induction of behavioural receptivity is not observed in this species (Wynne-Edwards et al., 1987b). Induced prolactin surges starting on the evening of day 1 (Barkley et al., 1978; Gunnet and Freeman, 1983) and increasing serum progesterone concentrations on day 3 of pregnancy (Smith et al., 1975) are among the earliest endocrine changes associated with preg-

${ }^{*}$ Correspondence and reprint requests.

Received 8 April 1993. nancy in small mammals with short cycles and a coitally induced luteal phase. The prolactin response in Djungarian hamsters is similar, with the exception of an additional diurnal surge of prolactin on day 2 of pregnancy (Erb and WynneEdwards, 1994) that coincides with an inhibition of progesterone release into the serum (Erb and Wynne-Edwards, 1993); this surge may be an earlier endocrine indication of pregnancy.

In all mammalian species, progesterone is essential for establishment and maintenance of pregnancy (Hodgen and Itskovitz, 1988). The corpus luteum that differentiates from the theca and granulosa cells of the ovulated follicle is the principal source of that progesterone in early pregnancy (Niswender and Nett, 1988). Those corpora lutea regress unless supported by a combination of luteotrophic and antiluteolytic polypeptides typically produced by the pituitary, the embryo, the uterus and, eventually, the placenta (Talamantes and Ogren, 1988; Soares et al., 1991). However, species vary considerably in the source of progesterone throughout pregnancy (luteal, placental or adrenal) and in the source of the polypeptides influencing progesterone synthesis and secretion (for review, see Hodgen and Itskovitz, 1988).

In light of the emergent value of the Djungarian hamster as a model for the study of comparative reproductive physiology, this study was conducted to characterize the 18 day Djungarian hamster pregnancy in terms of the concentrations of progesterone and oestradiol in serum and in secretory tissues, the concentration of prolactin in serum, and the morphology of the ovary the placenta and the developing fetus. 


\section{Materials and Methods}

\section{Animals}

Djungarian hamsters were descendents of a colony established in 1981 and most recently outbred against animals caught in Tuva, Siberia in 1990. The colony was maintained at $18^{\circ} \mathrm{C}$ on a $14 \mathrm{~h}$ light: $10 \mathrm{~h}$ dark schedule, with $00: 00 \mathrm{~h}$ corresponding to the middle of the dark phase. Animals were housed in $27 \mathrm{~cm} \times 21 \mathrm{~cm} \times 14 \mathrm{~cm}$ cages lined with wood shavings. Food (Purina lab chow) and water were provided ad libitum. Dim red light provided illumination during the dark portion of the light cycle and during behavioural tests conducted during the dark phase.

All females used in this study were adult virgins (17-43 g) between 90 and 180 days of age (mean $=131$ days). Males ( $>90$ days old) were not controlled for previous mating experience. Pairing occurred in the early afternoon, and pairs remained together after mating to minimize pregnancy blocking responses (Wynne-Edwards and Lisk, 1984; WynneEdwards et al., 1987a). Mating was confirmed by the direct observation of at least one behavioural ejaculation (Erb et al., 1993). Day I of pregnancy began at midnight (00:00 h) following the evening on which mating occurred.

\section{Collection of blood samples}

Blood samples were collected from all females, except those specifically used for sampling prolactin concentrations (see below), between 17:00 $\mathrm{h}$ and 19:00 $\mathrm{h}$ and the animals were then immediately killed by cervical dislocation for the collection of other tissues. Total handling time was less than $20 \mathrm{~s}$. Blood was collected from the orbit of the eye by the method of Wynne-Edwards et al. (1987b) into an unheparinized Pasteur pipette. It was immediately transferred from the pipette into a $1.5 \mathrm{ml}$ microfuge tube and allowed to clot for $24 \mathrm{~h}$ at $4^{\circ} \mathrm{C}$. Clots were removed, blood centrifuged at $1000 \mathrm{~g}$ at $4^{\circ} \mathrm{C}$ for $20 \mathrm{~min}$, and serum withdrawn and stored at $-20^{\circ} \mathrm{C}$ until assayed for hormone content.

Body mass $( \pm 1 \mathrm{~g}$ ) and the number of embryos visible in oviduct or uterine saline flushes (Erb and Wynne-Edwards, 1993), or visibly implanted in the uterus (days 6-17) were recorded for each female and used to confirm the pregnancy. The physical appearance of each corpus luteum was described and the fresh mass for each ovary was recorded to the nearest $0.1 \mathrm{mg}$. Corpora lutea were then dissected from the non-luteal portion of the ovary under $\times 400$ magnification in PBS. Total corpus luteum mass per ovary was recorded to the nearest $\mu \mathrm{g}$ (fresh mass). Corpora lutea (1-4 per female) and the non-luteal ovary were extracted individually into $250 \mu \mathrm{l}$ absolute ethanol and stored at $-20^{\circ} \mathrm{C}$ until assayed for progesterone and oestradiol content. For a subsample of pregnant females between days 8 and 12 of pregnancy, the right ovary was fixed, intact, in $10 \%$ buffered neutral formalin for histological analyses. One placenta from each female on days 14-17 was also crushed and extracted into $1 \mathrm{ml}$ absolute ethanol.

\section{Embryonic development}

In the course of several studies, a total of 54 uteri from pregnant females between days 6 and 18 of pregnancy were fixed in $10 \%$ buffered neutral formalin. Each was dissected at $\times 60$ magnification and both fetal and placental fixed masses were recorded. The stage of physical development of each embryo was described.

\section{Ovarian morphology and histology}

Tissues from three females on each of days 8,10 and 12 of pregnancy were prepared using standard histological techniques. Each ovary was embedded in paraffin wax and serially sectioned at $8 \mu \mathrm{m}$ before staining with Harris haematoxylin and $1 \%$ Eosin $Y$ (Humason, 1967). Ovarian thin sections were examined under a light microscope at $\times 100$ magnification for the presence of preovulatory follicles with a coalesced antrum and a definite stalk of granulosa cells surrounding the ova. Follicle diameter was measured to the nearest $10 \mu \mathrm{m}$ in the section that contained the nucleus or nucleolus of the oocyte. Largest and smallest dimensions of the follicle were recorded, and then averaged to give a mean diameter for each follicle.

Individual luteal cells were measured at $\times 400$ magnification. An independent volunteer measured ten luteal cells from each of two different fields of view for each corpus luteum. Largest and smallest dimensions of each luteal cell were determined by micrometer to the nearest $2.5 \mu \mathrm{m}$, and then averaged to give a diameter for each luteal cell.

\section{Progesterone and oestradiol radioimmunoassay}

The method for both the oestradiol and progesterone radioimmunoassays (progesterone antibody no. 337 and oestradiol antibody no. 244, supplied by G. D. Niswender, Colorado State University) has been validated previously in this species (Wynne-Edwards et al, 1987b; Erb and WynneEdwards, 1993). All samples were assayed in duplicate and serial dilutions were performed for analyses requiring less than $5 \mu \mathrm{l}$. Where two volumes are shown, the second dilution was used to assay samples that were outside the sensitivity range of the assay. Assay volumes used to determine progesterone concentrations were $5 \mu \mathrm{l}$ of serum, 5 or $1.25 \mu \mathrm{l}$ of corpus luteum extract, $2.5 \mu \mathrm{l}$ of non-luteal ovary extract and $250 \mu \mathrm{l}$ of placental extract (dried before assay). For oestradiol, assay volumes were $150 \mu \mathrm{l}$ of serum, $50 \mu \mathrm{l}$ of corpus luteum extract, 70 or $10 \mu \mathrm{l}$ of non-luteal ovary extract and $50 \mu \mathrm{l}$ of placental extract. Serum oestradiol concentrations in the Djungarian hamster are low (Wynne-Edwards et al., 1987b) and a maximum of only $500-700 \mu \mathrm{l}$ of serum can be collected per individual. Thus, duplicate determination of serum oestradiol concentrations was not always possible. The conservative limits of sensitivity in the progesterone assay were defined as $85 \%$ binding at $13.2 \mathrm{pg}$ per tube and $20 \%$ binding at $134.3 \mathrm{pg}$ per tube. The comparable limits for the oestradiol assay were 3.9 and $53.6 \mathrm{pg}$ per tube. Values outside assay limits were entered into the calculations as the limiting value. Interassay and intra-assay coefficients of variation were 9.8 and $13.2 \%$ for progesterone, respectively, and 8.6 and $12.8 \%$ for oestradiol, respectively, calculated from duplicate determinations for 18 progesterone and eight oestradiol assays 


\section{Daily patterns in prolactin secretion}

Dusk coincides with the period of maximum prolactin secretion of the coitally induced pituitary prolactin surge profile in rats (Freeman and Sterman, 1978), Golden hamsters (Terranova and Greenwald, 1979), and Djungarian hamsters (Erb and Wynne-Edwards, 1994) and the time of sample collection in this study. Where available, additional samples from other females bled by the same method during midday (07:30-11:30 h), which would coincide with nadir concentrations of prolactin during preimplantation (Erb and WynneEdwards, 1994) were also analysed. A total of 263 samples, of which 129 were taken during daylight, were therefore assayed for serum prolactin concentration.

\section{Prolactin radioimmunoassay}

The homologous Golden hamster prolactin assay used for radioiodination and radioimmunoassay was modified from that of A. F. Parlow (Pituitary Hormones and Antisera Centre, Harbor-UCLA Medical Centre, Los Angeles, CA) and that of F. Talamantes (Talamantes et al., 1984) using chloramine $T$ in a gaseous phase reaction for iodination (Butt, 1972).

For the assay, standards and unknown samples received $100 \mu \mathrm{l}$ of primary antisenum [anti-haPRL (rat; no. 7472988 from A. F. Parlow) in $2 \%$ normal rat serum at a working dilution of $1: 16000]$ and were allowed to incubate overnight at room temperature. On the second day, $100 \mu \mathrm{l}$ of $\left[{ }^{125} \mathrm{I}\right]$ prolactin was added at approximately 16000 c.p.m. per tube. On the third day, $100 \mu$ l of secondary antisenum [goat-anti-rat $\gamma$ globulin, (titer P-3, LOT no. 9TA05Y, Antibodies Inc, Davis, CA) diluted $1: 16]$ was added and allowed to incubate for $0.5 \mathrm{~h}$, followed by $100 \mu \mathrm{l}$ of $30 \%$ polyethylene glycol. Tubes were centrifuged at $5000 \mathrm{~g}$ for $30 \mathrm{~min}$ at $10^{\circ} \mathrm{C}$. Supernatants were aspirated and pellets counted for I min.

All serum samples were assayed in duplicate at 5,2 or $0.75 \mu \mathrm{l}$. The lower limit of assay sensitivity ( $85 \%$ binding) was $3.0 \mathrm{ng} \mathrm{ml}^{-1}$, while the upper limit $(20 \%$ binding) was $500 \mathrm{ng} \mathrm{ml}^{-1}$ in serum. Samples too high or low to measure were entered into the means as their limiting value. The interassay and intra-assay coefficients of variation were $8.7 \%$ and $13.7 \%$, respectively, calculated from duplicate determinations of 27 assays.

Validation of parallelism in the heterologous assay for use in the dwarf hamster involved parallelism of lactating female serum (range $0.1-1.0 \mu \mathrm{l}$ ) against triplicate determinations of a standard curve from 1.5 to $1500 \mathrm{pg}$ per tube. The sensitivity range was comparable to that of the homologous assay (30-300 pg per tube; Talamantes et al., 1984) at 15-390 pg per tube $(85-20 \%$ binding) with a LOGIT slope of -2.19 . (Validation available from A. F. Parlow at Pituitary Hormones and Antisera Centre, Harbor-UCLA Medical Centre.)

No Djungarian hamster placental lactogens have been identified or purified. Direct measurement of the crossreactivity of prolactin and placental lactogen (both peptides being structurally similar; Soares et al., 1991) was therefore not possible. Nevertheless, placentae isolated during late pregnancy were incubated for $30 \mathrm{~min}$ at $36^{\circ} \mathrm{C}$ in a shaking water bath in $1 \mathrm{ml}$ of Kreb's Ringer bicarbonate with glucose (KRBG, $\mathrm{pH} 7.6)$ and assayed with the haPRL primary antibody $(n=40$ plus a pool run in eight replicates and assayed for intra-assay variability and parallelism). At the $25 \mu \mathrm{l}$ sample volume, the assay would have detected as little as $0.9 \mathrm{ng}$ of prolactin per placenta. No sample contained measurable prolactin concentrations with average binding at $95.2 \%$ of total binding. The haPRL primary antibody therefore does not significantly crossreact with placental lactogens, if there are placental lactogens in Djungarian hamster placenta during late pregnancy.

\section{Ovarian support of late-term pregnancy}

While the relative importance of ovarian corpora lutea during pregnancy is best determined by direct luteectomy, such a technique has not yet been developed for the Djungarian hamster, since corpora lutea are numerous and often embedded in the follicular non-luteal ovary. Instead, to assess the importance of the ovary during late gestation, females were either bilaterally ovariectomized $(n=4)$ or sham operated $(n=4)$ on day 14 of pregnancy and monitored for vaginal bleeding or the birth of pups. Females that failed to give birth were killed two days after the expected date of parturition and the physical appearance of the uterus was described. Ovariectomy was conducted under xylazine (10 $\mathrm{mg} \mathrm{kg}^{-1}$ ) and ketamine (130 $\mathrm{mg} \mathrm{kg}^{-1}$, i.p.) anaesthesia with bilateral dorsal incisions for entry into the peritoneal cavity.

\section{Statistical analyses}

Statistical analyses used Statview ${ }^{\mathbb{R}}$ running on a Macintosh $\mathrm{SE} / 30$ computer. Results are expressed as means $\pm \mathrm{SEM}$. All measurements including mass, size, number, serum and luteal progesterone concentrations were normally distributed and analysed by parametric techniques. As no females were sampled repeatedly, all of the females were treated as independent data points. Analysis of variance (ANOVA) was used for comparisons between days and times of day. Provided that the overall test was significant, post-hoc analyses used the Fisher probable least squares difference (PLSD) test. Within-female variance in progesterone concentration per corpus luteum (I-4 per female were extracted) was small relative to betweenfemale variance. A mean corpus luteum progesterone concentration was therefore calculated for each female and this was used in subsequent analyses. Non-luteal ovary mass was calculated by subtraction of the total luteal mass from combined ovarian mass. All tests were two-tailed with a critical significance level of $P<0.05$.

\section{Results}

A mean of $6.70 \pm 0.15$ corpora lutea per female (range, 3-14) was found. During preimplantation the number of corpora lutea is equal to the number of eggs shed (Erb and Wynne-Edwards, 1993). By contrast, in half of the females during late pregnancy $(51 \%)$ the number of corpora lutea were not equal to the number of embryos. In $23 \%$ of those cases, the number of embryos exceeded the number of corpora lutea. In the remaining $77 \%$, the number of corpora lutea exceeded the number of embryos. Embryo losses before late pregnancy were more 
common than corpus luteum regression (binomial test, $P<0.01$ ).

There was no evidence of unilateral ovulation. The majority of females had equal numbers of corpora lutea and embryos on each side, and the difference between the number of corpora lutea in the two ovaries was normally distributed $(P>0.9)$ with a mean of $0.10 \pm 0.14$.

The number of corpora lutea or embryos in a female were not useful as predictors of serum, individual corpus luteum or summed corpus luteum progesterone concentration $(P>0.3$ in all cases). All measurements were considered in all analyses. Only total corpus luteum mass and mean corpus luteum progesterone concentration are reported here. None of the results was substantively different for the alternative measures.

Female body masses were randomly distributed across samples $\left(F_{1,99}=2.58, P=0.11\right)$ but combined ovarian mass increased significantly with increasing body mass $\left(F_{1,103}=83.44, P<0.01\right.$; slope $\left.=0.84\right)$. Analyses therefore used the ratio of paired ovarian mass:body mass to correct for this source of variance.

\section{Ovarian morphology and histology}

Ovarian mass and composition changed significantly throughout pregnancy (ratio of paired ovarian mass:body mass, $F_{11,96}=10.56$; ratio of total corpus luteum mass:non-luteal ovary mass, $F_{11,87}=26.78$ (Fig. 1a); total corpus luteum mass, $F_{11,87}=33.13$; total non-luteal ovary mass, $F_{11,87}=2.52$ (Fig. Ib); $P<0.01$ in all cases). During the first four days of preimplantation pregnancy, the non-luteal ovary decreased in mass as the corpora lutea increased in mass. During midpregnancy, each remained stable. These combined effects resulted in a stable ratio of paired ovarian mass:body mass between day 1 and day 11 of pregnancy. On day 12, paired ovarian mass increased as a result of a significant increase in total corpus luteum mass.

This increase in corpus luteum mass was accompanied by an increase in the number and diameter of blood vessels visible on the basement membrane of the corpus luteum. In thin sections under the light microscope, luteinized cells were typically squamous with condensed nuclei. Individual luteal cells from the Djungarian hamster at day 12 of pregnancy were significantly larger than those on day 8 or day 10 of pregnancy $\left(F_{2,20}=25.17, \quad P<0.01\right.$; post-hoc Fisher PLSD $\left.P<0.05\right)$, increasing from an average dimension of $15.9 \pm 0.2 \mu \mathrm{m}$ on day 10 to $19.5 \pm 0.5 \mu \mathrm{m}$ on day 12 , with no significant variation within or between individuals.

Large, preovulatory follicles with a well-formed stalk of granulosa cells were not found in the pregnant ovary on day 8 or 10 but were consistently present on day 12 . The mean diameter of those preovulatory follicles was $560 \pm 10 \mu \mathrm{m}$.

\section{Embryonic and placental development}

The fetus and placenta could not be distinguished by morphology until day 10 of pregnancy and therefore they could not be dissected for fresh mass measurements. Fixed masses of the fetus and placenta from day 10 to day 16 of
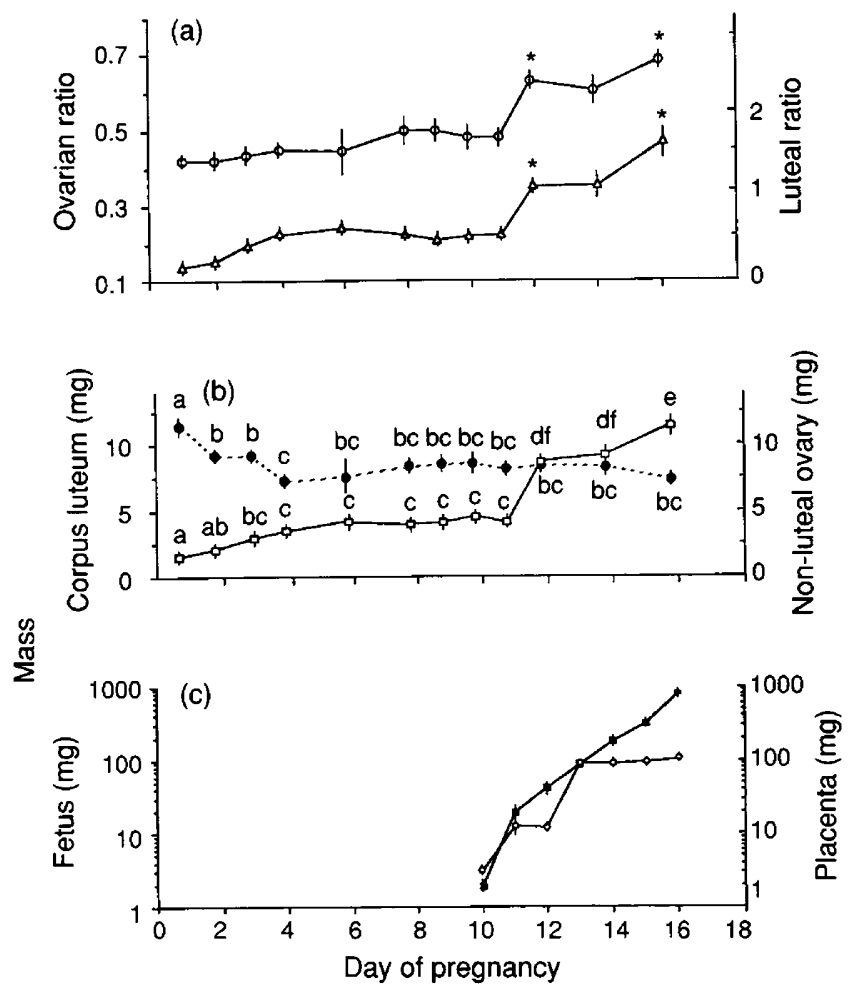

Fig. 1. (a) Ratio of combined ovarian mass:body mass $(O)$ and total luteal mass:non-luteal ovary mass $(\Delta)$ during pregnancy (mean \pm SEM; $n=5-12$ ). Asterisks $\left({ }^{*}\right)$ represent a significant difference from the previous day (Fisher PLSD, $P<0.05$ ). (b) Comparable total luteal mass (c) and total non-luteal ovary mass $(\bullet)$ during pregnancy. Values with different letters are significantly different from each other (Fisher PLSD, $P<0.05$ ). (c) Fixed mass for the fetus ( $\bullet$ ) and placenta (o) are shown for days $10-16$ of gestation (mean \pm SEM; $n=6$ ). Neither the fetus nor placenta could be distinguished by morphology before day 10 .

gestation are shown (Fig. Ic). Fetal mass increased exponentially during the second half of pregnancy (regression, $R^{2}=0.85$ ). From day 14 to day 17 the fetus was growing so quickly that the fetal mass was a reliable indicator of the day of gestation. Embryonic development included (1) translucent skin with the digits proximally webbed, the auditory meatus visible and a thin pigment line surrounding the eye (noon, day 14), (2) digit separation and pinnae beginning to cover the auditory meatus (noon, day 15), (3) clawed digits and an eyelid forming (noon, day 16), and (4) loose pink skin, elongated feet and fused eyelids (noon, day 17) before birth in the afternoon of day 18 . The discoid placenta attained its maximum mass after a tenfold increase between day 12 and day 13 .

\section{Progesterone}

Concentrations of progesterone in the serum changed significantly during pregnancy $\left(F_{13,121}=10.64, P<0.001\right)$ (Fig. 2a). During early pregnancy (days $1-4$ ), a twofold increase in serum progesterone concentration occurred, rising from day 1 to days 3 and 4 . Serum progesterone declined significantly on day 6 and then stabilized during days 8-11. A second Downloaded from Bioscientifica.com at 04/26/2023 10:36:45AM 

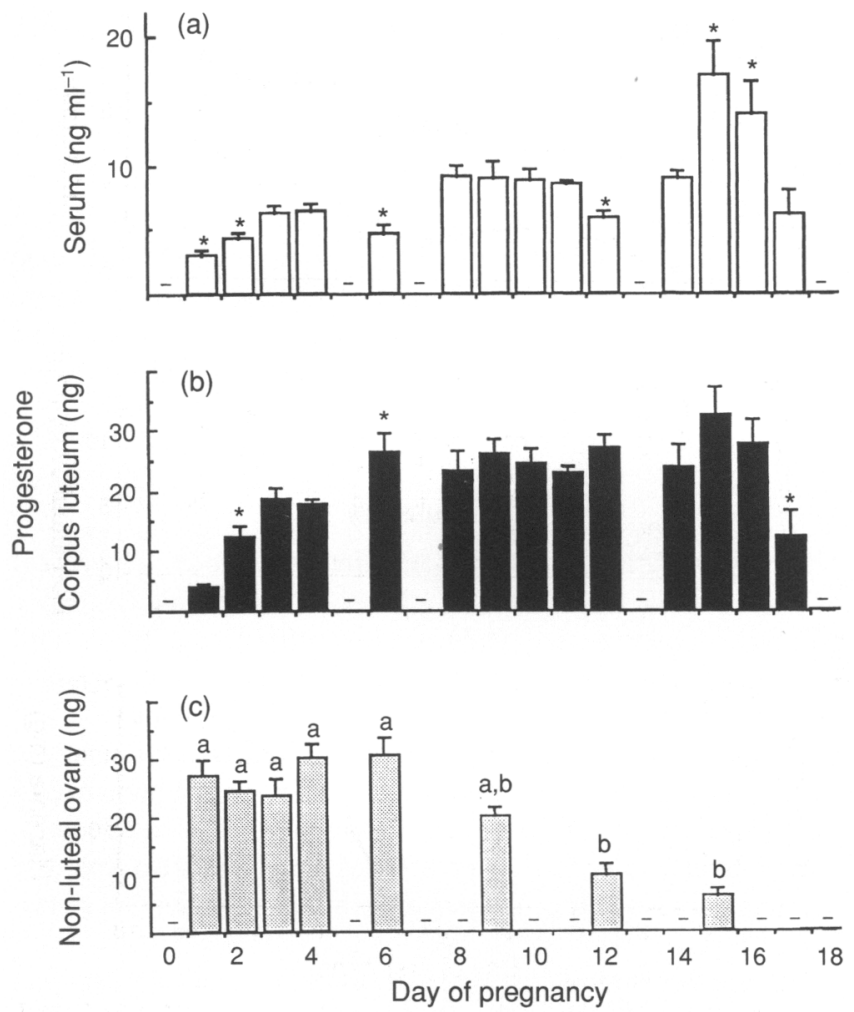

Fig. 2. (a) The concentration of serum progesterone during pregnancy (mean \pm SEM; $n=6-14$ ). Dashes (-) identify days on which no sample was collected. Asterisks (*) denote serum progesterone concentrations significantly different from that on day 4 of pregnancy (Fisher PLSD, $P<0.05)$. (b) Progesterone concentration of extracted corpus luteum (ng per corpus luteum) during pregnancy (mean $\pm \mathrm{SEM} ; n=6-$ 13). Asterisks (*) denote concentrations significantly different from the previous sample (Fisher PLSD, $P<0.05$ ). (c) The amount of progesterone extracted from the non-luteal ovary (mean \pm SEM; $n=8-16$ ) on days $1-4,6,9,12$ and 15 of pregnancy. Values with different letters are significantly different from each other (Fisher PLSD, $P<0.05)$.

significant decline in serum progesterone was also seen on day 12. Between day 14 and day 15, serum progesterone doubled rapidly. A sharp decline in serum progesterone on day 17 preceded parturition on day 18 .

A total of 398 corpora lutea (from 104 females) were individually extracted and assayed for progesterone content. Extractable corpus luteum progesterone concentration is shown in Fig. 2b; this also changed significantly during pregnancy $\left(F_{13,103}=9.233, P<0.001\right)$, rising from day 1 to days 3 and 4 . On day 6 , the progesterone content of the corpus luteum increased significantly, then remained stable until day 16 of gestation before decreasing on day 17. Corpus luteum mass increased significantly during late pregnancy, but corpus luteum progesterone content did not.

The extractable progesterone content of the non-luteal ovary is shown (Fig. 2c). Non-luteal ovary progesterone concentration also changed significantly during pregnancy $\left\langle F_{7,134}=3.32, P<0.01\right)$. Concentrations of progesterone were high on days 1-6 and then declined to low concentrations during days $12-16$.
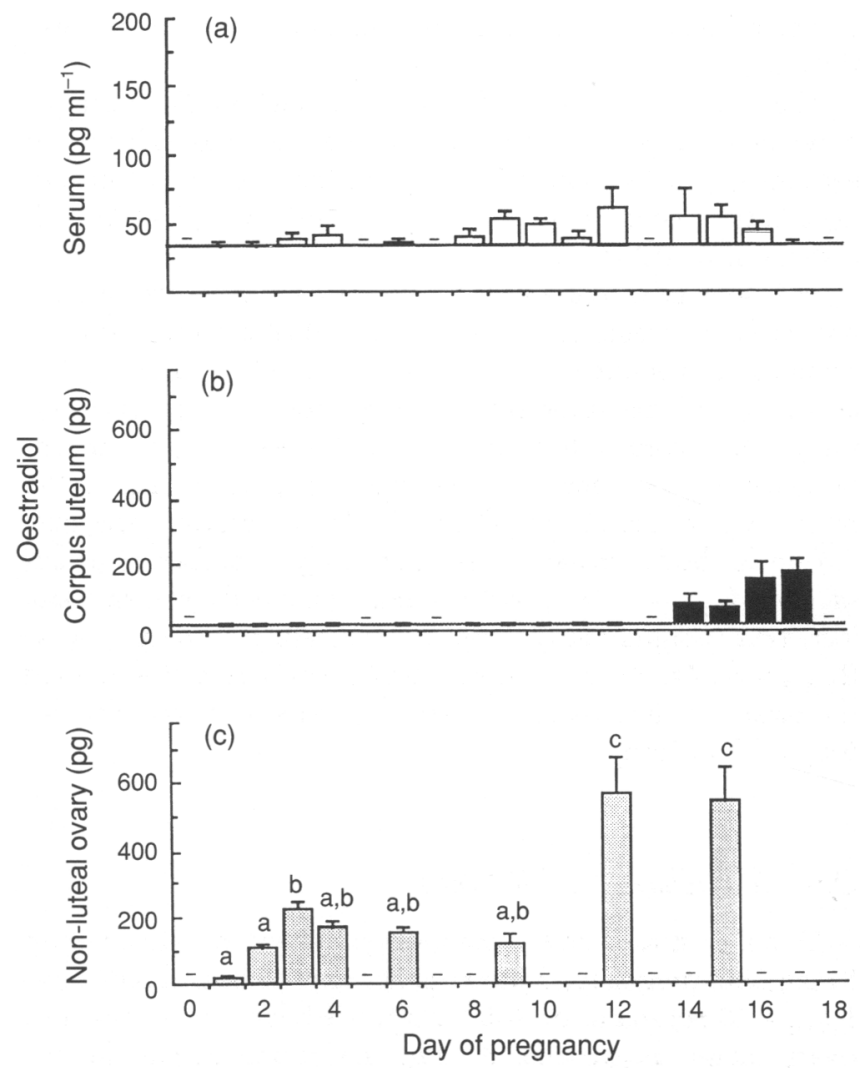

Fig. 3. (a) The concentration of serum oestradiol during pregnancy (mean $\pm \mathrm{SEM} ; n=6-14$ ). The dotted line represents the lower limit of detection of the assay. Dashes ( - ) identify days on which no sample was collected. (b) Extracted corpus luteum oestradiol concentration (pg per corpus luteum) during pregnancy (mean \pm SEM; $n=5$ ). (c) The amount of oestradiol extracted from the non-luteal ovary (mean \pm SEM; $n=8-16$ ) on days $1-4,6,9,12$ and 15 of pregnancy. Values with different letters are significantly different from each other (Fisher PLSD, $P<0.05$ ).

Extractable progesterone content in placenta was measured reliably by the radioimmunoassay and was minimal. An average of only $0.33 \pm 0.08 \mathrm{ng}$ of progesterone per complete placenta was found $(n=6)$.

The progesterone ratio (ng per corpus luteum:ng $\mathrm{ml}^{-1}$ in serum) changed significantly through gestation $\left(F_{13,103}=3.71\right.$, $P<0.01$ ) with significant peaks occurring on day 6 relative to all days but day 12 , and on day 12 relative to days $1,2,8$ and 14-17 (Fisher PLSD, $P<0.05$ ).

\section{Oestradiol}

Serum oestradiol concentrations throughout pregnancy are shown in Fig. 3a. Of 220 pregnant females, the oestradiol concentrations of 176 were below the conservative sensitivity limit of the assay when measured in $150 \mu \mathrm{l}$ of serum and rounded to $32.7 \mathrm{pg} \mathrm{ml}^{-1}$. Mean comparisons during gestation were therefore not appropriate as they would result in low estimates of error and artificially high confidence in mean values. Instead, contingency table analyses were used to compare the number of females in each of three phases of Downloaded from Bioscientifica.com at 04/26/2023 10:36:45AM 


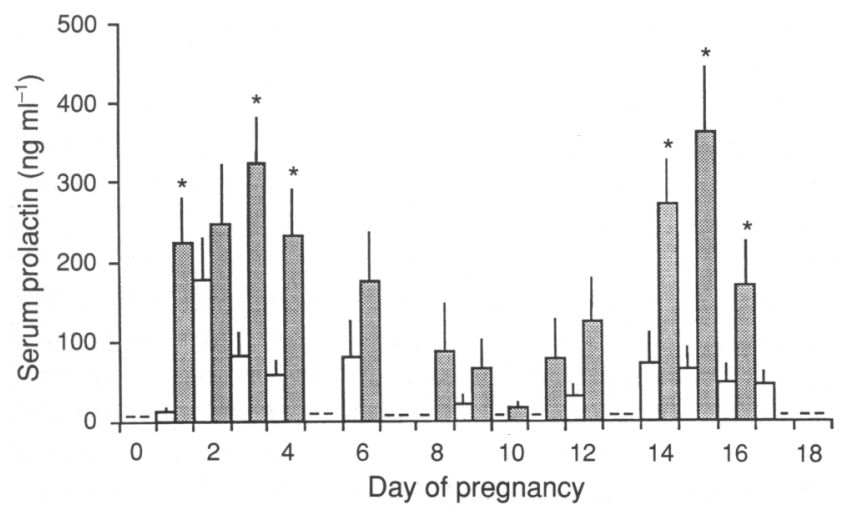

Fig. 4. Serum concentrations of prolactin (ng $\mathrm{ml}^{-1}$ ) during pregnancy (mean \pm SEM; $n=6-22$ ) in daylight $(\square)$ and at dusk (畻). Dashes ( identify days on which no sample was collected. Asterisks (*) denote significant differences between daylight and dusk samples on a given day ( $t$ tests, $P<0.05$ ).

pregnancy: early (days $1-6$ ); mid (days $8-12$ ); and late (days 14-17). These three phases had easily detectable oestradiol concentrations. There was a significant effect of phase of pregnancy $\left(\chi_{\text {d.f. }=2}^{2}=14.04, P<0.01\right)$, with a larger number of mid-pregnant $(33 \%)$ than early-pregnant $(8 \%)$ or late-pregnant (15\%) females having detectable oestradiol concentrations $\left(\chi_{\text {d.f. }=1}^{2}=4.50, P<0.05\right)$.

A total of 68 corpus luteum extractions were assayed for oestradiol with a sensitivity that would have detected $19.5 \mathrm{pg}$ per corpus luteum. Neither early-pregnant (days 1-4, $n=28$ females) nor mid-pregnant (days $8-12, n=40$ females) corpora lutea contained measurable oestradiol concentrations, with average binding in the assay at $98.6 \%$ of total binding. However, on days $14-17$, oestradiol was detectable in corpora lutea (Fig. 3b).

The total oestradiol extractable from the non-luteal ovary is shown (Fig. 3c) and was easily detectable by the assay. The non-luteal oestradiol concentration changed significantly during pregnancy $\left(F_{7,134}=3.32, P<0.01\right)$, increasing during early pregnancy but remaining comparatively low except for a fourfold increase seen in the samples for days 12 and 15 .

\section{Daily patterns in prolactin secretion}

Serum prolactin concentrations during pregnancy are shown (Fig. 4). For the days on which samples taken during daylight hours and at dusk were available, both time of day $\left(F_{1,213}=37.98, P<0.01\right)$ and day of pregnancy $\left(F_{9,213}=2.03\right.$, $P<0.03)$ significantly affected serum prolactin concentrations. This was the result of high prolactin concentrations at dusk and low concentrations during daylight during early (days 1, 3, 4) and late gestation (days 14-16), when light and dusk samples from the same day were significantly different from each other ( $t$ tests; $P<0.05$ ). The absence of a difference in prolactin concentrations during daylight and at dusk on day 2 of pregnancy is the result of a diurnal prolactin surge unique to that day of preimplantation (Erb and Wynne-Edwards, in press). Both the absolute concentration of serum prolactin (reaching a minimum value of $7.98 \pm 2.75 \mathrm{ng} \mathrm{ml}^{-1}$ on day 10) and the amplitude of the daylight-dusk rhythm in prolactin concentrations were reduced during mid-pregnancy.

\section{Ovarian support of late-term pregnancy}

All sham-operated (litter size of 4-7 pups) but no bilaterally ovariectomized females gave birth successfully. The presence of healthy fetuses was confirmed in all females during surgery on day 14. Post-mortem examination of ovariectomized females on day 20 confirmed the presence of necrotic tissue from the recent pregnancy.

\section{Discussion}

The pregnancy of the Djungarian hamster Phodopus campbelli is organized into three distinct phases. The first phase (early pregnancy) begins at ovulation and fertilization (day 1), and continues to implantation (day 5). The second phase (midpregnancy) begins on day 6 and continues until day 12 . The third phase (late pregnancy) concludes with parturition in the middle of day 18 . These data suggest that the maintenance of the pregnancy through each of these phases is endocrinologically different, not only from the other phases but also from the predictions based on pregnancy in other small mammals in the laboratory.

The present results confirm those of recent studies that investigated preimplantation in the Djungarian hamster (Erb and Wynne-Edwards, 1993, 1994) and place those results in the wider context of the complete pregnancy. As is typical in small rodents (Smith et al., 1975), serum progesterone concentrations first increase above oestrous cycle concentrations (WynneEdwards et al., 1987b) late on day 3 of pregnancy. However, this is not the first endocrine signal associated with early pregnancy. On day 2 of pregnancy, there is an accumulation of progesterone in the corpora lutea, which is released into the serum during an oestrous cycle but is not released into the serum during early pregnancy (Erb and Wynne-Edwards, 1993), and a single, diurnal, prolactin surge into the serum that is in addition to the coitally induced (Gunnet and Freeman, 1983) dusk and dawn prolactin surges established by the evening of day 1 of pregnancy (Erb and Wynne-Edwards, 1994). The patterns established by day 4 of preimplantation continue into day 6 of pregnancy when several endocrine transitions occur. There is a transient increase in the corpus luteum:serum progesterone ratio as a result of a decrease in serum progesterone and a simultaneous increase in progesterone content of the corpus luteum. There is also a transient increase in oestradiol content in the non-luteal ovary, a loss of the dusk prolactin surges and a halt in the growth of the corpus luteum. The last time at which the blastocyst can be flushed from the uterine lumen by saline is midnight on day 4 (Erb and Wynne-Edwards, 1993). By analogy with other species, both the developing embryo (e.g. Wiltbank et al., 1992; Wu, 1985) and the uterus (e.g. Tamada et al., 1991) secrete compounds that serve as signals to the maternal hypothalamus, pituitary or corpus luteum that viable embryos are implanting (Hodgen and Itskovitz, 1988).

Djungarian hamster females with an induced pseudopregnancy mate again on the tenth day (Edwards and WynneEdwards, in press). By the eighth day, corpus luteum function is Downloaded from Bioscientifica.com at 04/26/2023 10:36:45AM 
already severely impaired relative to that of the pregnant female, and serum progesterone concentrations are low. These data support the prediction that the critical endocrine transitions on day 6 represent signals or responses to the implantation of viable embryos in the uterus. A similar time-course has been established for the Golden hamster (Greenwald and Bast, 1978; Greenwald, 1985). The most sensitive period for pregnancy block in Djungarian hamsters is 24-48 h after mating (day 2 of pregnancy; Wynne-Edwards et al., 1987a) and results in a return to behavioural oestrus and ovulation on the fourth day, as if oestrous cyclicity had not been interrupted. Day 6 may also be a sensitive time for termination of the investment of time and energy in a failed reproductive attempt.

Mid-pregnancy was characterized by a stable progesterone concentration of the corpus luteum, a stable serum progesterone concentration, and stable morphological characteristics of the ovary and corpus luteum until day 11 . Over the same period, the non-luteal ovary actively produced and secreted oestradiol, and pituitary prolactin surges were reduced. On day 12 , each of these variables changed again. Serum oestradiol concentration peaked while progesterone declined, preovulatory follicles were found in the non-luteal ovary, corpora lutea resumed growth through enlargement of individual cells, and placental mass increased by a factor of ten. This transition corresponds to the completion of the discoid placenta and the start of the rapid growth phase of the embryo, and also appears to be a critical transition in the endocrine regulation of pregnancy of Djungarian hamsters.

Like Djungarian hamsters, Golden hamsters also have a peak in the number of large follicles in the ovary on day 12 (Greenwald, 1964) and are maximally responsive to hCGinduced ovulation on that day (Greenwald, 1967). The function of these large follicles is unknown, as the Golden hamster does not have a post-partum ovulation and the rat, which does have a post-partum ovulation, does not have large follicles in the ovary until day 20 of the 22 day pregnancy (Greenwald, 1966). As the Djungarian hamster has both a fertile post-partum oestrus and large follicles on day 12 of pregnancy, the function of the large follicles remains unknown. It is possible that they luteinize and replace the original corpora lutea (Westfahl, 1993), although no evidence of corpus luteum regression was found, or they may remain quiescent in the ovary until parturition.

In late pregnancy, there was a doubling in the circulating concentration of progesterone in the serum and in the size and vascularization of individual corpora lutea. In spite of the increasing concentrations of progesterone in the serum, the corpus luteum during late pregnancy did not contain more extractable progesterone than did the corpus luteum at midpregnancy, although it, as well as the non-luteal ovary, did contain significant quantities of oestradiol. Thus, while the reservoir of progesterone was unchanged, the extractable progesterone per mg corpus luteum decreased by $50 \%$, suggesting either an increase in the rate of progesterone secretion or a change in the metabolic clearance rate of progesterone. Nevertheless, all of this evidence is consistent with a critical role for luteal progesterone in the maintenance of late pregnancy. In addition, as would be predicted if the corpora lutea are essential to maintain late pregnancy, late pregnancies failed to survive bilateral ovariectomy and placentae contained little extractable progesterone.

Although the corpora lutea are essential for late pregnancy in many species, their continued function is always dependent upon a combination of luteotrophic and antiluteolytic factors that are not endogenous to the corpus luteum (Niswender and Nett, 1988). During late pregnancy, the placenta is usually the source of placental lactogens (analogues to pituitary prolactin), chorionic gonadotrophins, a variety of other luteotrophic and antiluteolytic signals, and often progesterone itself. Pregnancy in some species can therefore survive both late gestation ovariectomy (luteectomy) and hypophysectomy, whereas in other species, either the corpus luteum or both the pituitary and the corpus luteum are required and may continue to function after hysterectomy (for review, see Hodgen and Itskovitz, 1988). Even within a relatively small phylogenetic group such as the rodents, there is variability between species. However, pregnancies in rats, mice and golden hamsters all survive late-term hypophysectomy (Hodgen and Itskovitz, 1988).

Djungarian hamsters appear to be an exception to that pattern. They resume a pattern of alternating daily surge and nadir concentrations of prolactin in late pregnancy when the corpora lutea are growing, healthy and secreting large quantities of progesterone. The pituitary is the obvious source of this prolactin as the antibody used in this study recognizes large quantities of prolactin in pituitaries, which were collected from hamsters with preimplantation embryos (Erb and WynneEdwards, 1994), but completely fails to detect prolactin in placental incubations in the same medium during late pregnancy. Thus, the placenta of the Djungarian hamster does not appear to play a major role in steroid biosynthesis and may not play a luteotrophic role through placental lactogens. If pituitary prolactin is the luteotrophic stimulus of late pregnancy in Djungarian hamsters, treatment with the dopamine agonist $\mathrm{CB}$ 154 (bromoergocryptine) should reduce circulating prolactin without impairing other aspects of the hypothalamo-pituitaryovarian axis (Stroud et al., 1985) and cause pregnancy failure in dwarf hamsters during late pregnancy.

The adaptive value of pituitary prolactin regulation of late pregnancy is not clear. The placenta is in intimate contact with the fetus and therefore ideally placed to monitor fetal viability and transduce that information into a systemic signal that functions at the level of the ovary and the pituitary. However, reproduction in Phodopus is sensitive to key environmental stimuli including gestational photoperiod (Horton et al., 1992), core body temperature (Scribner and Wynne-Edwards, 1994), and signals from a breeding male to initiate spontaneous oestrous cycles (Erb et al., 1993) and maintain pregnancies (Wynne-Edwards et al., 1987a), each of which is integrated at the level of the hypothalamus. Small-bodied, short-lived rodents in extreme habitats experience strong natural selection for rapid reproductive cycles and early detection of failed pregnancies (Bronson, 1989). Direct pituitary involvement in pregnancy, and several sensitive times for the termination of investment in a pregnancy may be adaptive in those species.

The authors would like to thank $C$. Tweedie for her invaluable assistance in collecting these data. NIDDK kindly supplied the hormones for iodination, antiserum and reference preparations for rat Downloaded from Bioscientifica.com at 04/26/2023 10:36:45 AM 
prolactin. Hamster prolactin for iodination and the antiserum was supplied by A. F. Parlow. This study was supported by an NSERC research grant to $\mathrm{K}$. E. Wynne-Edwards, an NSERC post-graduate award to H. E. Edwards, and NSERC summer undergraduate awards to K. L. Jenkins and L. C. Mucklow.

\section{References}

Barkley MS, Bradford GE and Geschwind II (1978) The pattern of plasma prolactin concentration during the first half of mouse gestation Biology of Reproduction 19 291-296

Bronson FH (1989) Mammalian Reproductive Biology. The University of Chicago Press, Chicago

Butt WR (1972) The iodination of follicle stimulating and other hormones for radioimmunoassay Joumal of Endocrinology 55 453-454

Carter CS, Getz LL and Cohen-Parsons M (1986) Relationships between social organization and behavioural endocrinology in a monogamous mammal. In Advances in the Study of Behaviour, pp 109-145 Eds IS Rosenblatt, C Beer MC Busnel and PJB Slater. Academic Press, New York

Edwards HE and Wynne-Edwards KE Spontaneous termination of an induced pseudopregnancy in the Djungarian hamster, Phodopus campbelli Hormones and Behavior (in press)

Erb GE and Wynne-Edwards KE (1993) Pre-implantation endocrinology in the Djungarian hamster (Phodopus campbelli): progesterone, oestrogen, corpora lutea and embryonic development Biology of Reproduction 49 822-830

Erb GE and Wynne-Edwards KE (1994) Prolactin, follicle stimulating hormone and luteinizing hormone levels during preimplantation in the Djungarian hamster (Phodopus campbelli) Biology of Reproduction 50 1328-1333

Erb GE, Edwards HE, Mucklow LC, Jenkins KL and Wynne-Edwards KE (1993) Induced components in the spontaneous ovulatory cycle of the Djungarian hamster, Phodopus campbelli Physiology and Behaviour 54 955-959

Freeman ME and Sterman JR (1978) Ovarian steroid modulation of prolactin surges in cervically stimulated ovariectomized rats Endocrinology $\mathbf{1 0 2}$ $1915-1920$

Greenwald GS (1964) Ovarian follicular development in the pregnant hamster Anatomical Record 148 605-609

Greenwald GS (1966) Ovarian follicular development and pituitary FSH and LH content in the pregnant rat Endocrinology $17572-578$

Greenwald GS (1967) Induction of ovulation in the pregnant hamster American Joumal of Anatomy 121 249-258

Greenwald GS (1985) Endocrinology of the pregnant hamster. In The Hamster, pp 53-71 Ed. HI Siegel. Plenum Press, New York

Greenwald GS and Bast JD (1978) Hormone patterns in pregnant or pseudopregnant hamsters after unilateral ovariectomy or hysterectomy Biology of Reproduction 18 658-662

Gurnet JW and Freeman ME (1983) The mating-induced release of prolactin: A unique neuroendocrine response Endocrine Reviews 4 44-6I

Hodgen GD and Itskovitz J (1988) Recognition and maintenance of pregnancy. In The Physiology of Reproduction, pp 1995-2022 Eds E Knobil and JD Neill. Raven Press, New York

Horton TH, Ray SL, Rollag MD, Yellon SM and Stetson MH (1992) Maternal transfer of photoperiodic information in Siberian hamsters: effects of melatonin implants are dependent on photoperiod Biology of Reproduction 47 $291-296$
Humason GL (1967) Animal Tissue Techniques WH Freeman and Company, San Francisco

Murphy MR (1985) History of the capture and domestication of the Syrian Golden hamster (Mesocricetus auratus Waterhouse). In The Hamster, pp 3-22 Ed. HI Seigel. Plenum Press, New York

Niswender GD and Nett TM (1988) The corpus luteum and its control. In The Physiology of Reproduction, pp 489-519 Eds E Knobil and JD Neill. Raven Press, New York

Rissman EF (1990) The musk shrew, Suncus murinus, a unique animal model for the study of female behavioural endocrinology Journal of Experimental Zoology 4 207-209

Scribner SJ and Wynne-Edwards KE (1994) Disruption of body temperature and behavior rhythms during reproduction in dwarf hamsters (Phodopus) Physiology and Behavior 55 361-369

Smith MS, Freeman ME and Neill JD (1975) The control of progesterone secretion during the estrous cycle and early pseudopregnancy in the rat: prolactin, gonadotropin and steroid levels associated with rescue of the corpus luteum of pseudopregnancy Endocrinology 96 219-226

Soares MJ, Faria TN, Roby KF and Deb S (1991) Pregnancy and the prolactin family of hormones: co ordination of anterior pituitary, uterine, and placental expression Endocrine Reviews 12 402-423

Stroud CM, Noder PF and Whitsett JM (1985) Bromoergocryptine decreases serum prolactin and delays sexual maturation in male Golden hamsters Biology of Reproduction 32 1191-1199

Talamantes F and Ogren L (1988) The placenta as an endocrine organ: polypeptides. In The Physiology of Reproduction, pp 2093-2144 Eds E Knobil and JD Neill. Raven Press, New York

Talamantes F, Marr G, DiPinto M and Stetson M (1984) Prolactin profiles during the estrous cycle and pregnancy in hamsters as measured by homologous RIA American Joumal of Physiology 247 126-129

Tamada H, Das SK, Andrews GK and Sudhansu KD (1991) Cell-type-specific expression of transforming growth factor- $\alpha$ in the mouse uterus during peri-implantation period Biology of Reproduction 45 365-372

Terranova PF and Greenwald GS (1979) Antiluteinizing hormone: chorionic influence on steroid and gonadotropin concentrations and superovulation in the pregnant hamster Endocrinology 104 1013-1019

Westfahl PK (1993) Comparison of luteinized unruptured follicles and corpora lutea: steroid hormone production and response to luteolytic and luteotropic agents Biology of Reproduction 48 807-814

Wiltbank MC, Wiepz GJ, Knickerbocker JJ, Belfiore CL and Niswender GD (1992) Proteins secreted from early ovine conceptus block the action of prostaglandin $F_{2 \alpha}$ on large luteal cells Biology of Reproduction 46 475-481

Wu JT (1985) Metabolism of progesterone by hamster blastocyst and the ontogeny of progesterone metabolic capability Biology of Reproduction 33 53-59

Wynne-Edwards KE and Lisk RD (1984) Djungarian hamsters fail to conceive in the presence of multiple males Animal Behaviour 32 626-628

Wynne-Edwards KE, Huck UW and Lisk RD (1987a) Influence of pre- and post-copulatory pair contact on pregnancy in Djungarian hamsters, Phodopus campbelii Journal of Reproduction and Fertility 80 241-249

Wynne-Edwards KE, Terranova PF and Lisk RD (1987b) Cyclic Djungarian hamsters, Phodopus campbelli lack the progesterone surge normally associated with ovulation and behavioural receptivity Endocrinology 120 1308-1316 